\title{
A Case of Possible Doxycycline-Resistant Scrub Typhus
}

\author{
${ }^{1}$ Division of Pulmonary Medicine, ${ }^{2}$ Division of Infectious Medicine, Eulji University School of Medicine; \\ ${ }^{3}$ Internal Medicine, Sun General Hospital, Daejeon, Korea \\ Dong Jib Na, M.D. ${ }^{1}$, Sang Hoon Han, M.D. ${ }^{3}$, Kyung Min Moon, M.D. ${ }^{1}$, Dong Jin Kim, M.D. ${ }^{1}$, \\ Yang Deok Lee, M.D. ${ }^{1}$, Yong Seon Cho, M.D. ${ }^{1}$, Min Soo Han, M.D. ${ }^{1}$, Hee Jung Yoon, M.D. ${ }^{2}$
}

\section{Doxycycline 내성이 의심된 Scrub Typhus}

니동집 ${ }^{1}$, 한상훈 ${ }^{3}$, 문경민 ${ }^{1}$, 김동진 ${ }^{1}$, 이양덕 ${ }^{1}$, 조용선 ${ }^{1}$, 한민수 ${ }^{1}$, 윤희정 ${ }^{2}$

${ }^{1}$ 을지의과학대학교 호흡기내과, ${ }^{2}$ 감염내과, ${ }^{3}$ 대전 선병원 내과

쯔쯔가무시병은 추수 시기에 유행하는 대표적인 급성 열성질환으로 여전히 증가 추세에 있다. 의심되는 환자에게 Doxycycline 투여 후 급속한 해열이 질환의 독특한 특징이기도 한데 Doxycycline 투여 96시간 후에도 지속적인 고열과 근육통이 있었던 환자에게 Clarithromycin으로 변경 후 급속한 해열과 함께 증상이 호전된 증례를 보고한다.

(Tuberc Respir Dis 2007; 62: 545-548)

Key words: Clarithromycin, Doxycycline, Scrub typhus.

\section{INTRODUCTION}

Scrub typhus is an acute, febrile disease, caused by $O$. tsutsugamushi, which is transmitted to humans by bites of larval-stage trombiculid mites known as chiggers. An eschar and regional lymphadenopathy often develop at the site of inoculation, and may be followed by a systemic infection ranging in severity from symptomless to fatal. The annual incidence of this disease has increased sharply in Korea; 6,784 cases were reported in $2005^{1}$.

Response to treatment with doxycycline or chloramphenicol is generally rapid and life-saving ${ }^{2}$. $O$. tsutsugamushi infection is generally so responsive to treatment that if fever has not abated within 48 hours after therapy, the diagnosis is considered to be unlikely ${ }^{3}$.

The authors report a 43-year-old male with

Address for correspondence: Dong-Jib Na, M.D., Ph.D.

Division of Pulmonary Medicine, Department of

Medicine, Eulji University School of Medicine, 1036

Dunsan 2(i)-dong, Seo-gu, Daejeon, 302-799, Korea

Phone: 82-42-611-3154, Fax: 82-42-611-3853

E-mail: djna13@gmail.com

Received: Apr. 5. 2007

Accepted: May. 11. 2007 possible doxycyline-resistant scrub typhus, who continued to have fever and myalgia 96 hours after doxycycline treatment, but promptly responded to treatment with substituted clarithromycin.

\section{CASE REPORT}

This 43-year-old male farmer presented with complaints of fever, generalized myalgia and headache for 3 days duration. He drank frequently alcohol and took medicine for depression. On examination, he was febrile with a temperature of $37.8^{\circ} \mathrm{C}$. There were generalized maculopapular rashes and eschar on the right chest, but no conjunctival suffusion and lymphadenopathy. The cardiopulmonary and neurologic examinations were unremarkable.

Laboratory results were as follows: WBC count

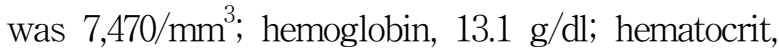
37\%; platelets, 159,000/ $\mathrm{mm}^{3}$; ESR, $20 \mathrm{~mm} / \mathrm{hr}$; Creactive protein, $12.49 \mathrm{mg} / \mathrm{dL} ; \mathrm{BUN}, 13.8 \mathrm{mg} / \mathrm{dL}$; and creatinine, $0.9 \mathrm{mg} / \mathrm{dL}$; albumin, 3.7g/dl; aspartate transaminase, $58 \mathrm{U} / \mathrm{L}$; alanine transaminase, 38 $\mathrm{U} / \mathrm{L} ; \mathrm{LDH}, 526 \mathrm{U} / \mathrm{L}$. Chest X-ray and urine were normal.

He was empirically started on doxycycline for 


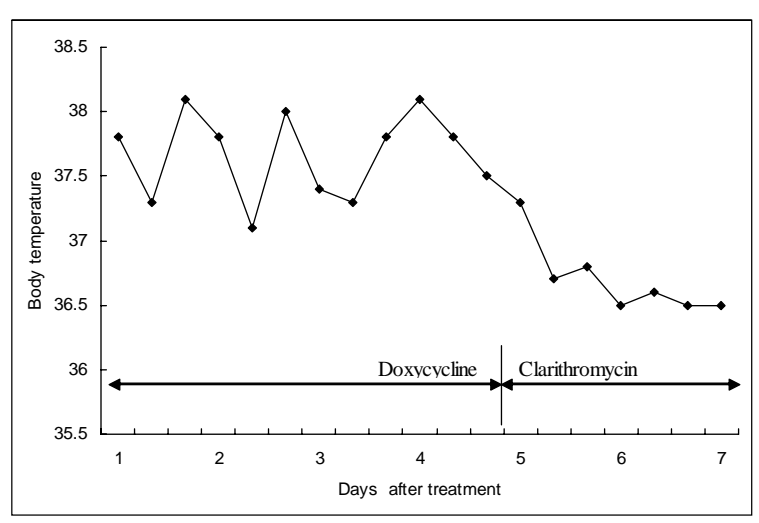

Figure1. Change in body temperatrure over the time. Sustained fever despite 96 hours doxycycline treatment promptly subsided with substituted clarithromycin.

possible scrub typhus. However, he continued to have persistent fever, myalgia, and headache while receiving doxycycline treatment for 96 hours. Antibody titer against $O$. tsutsugamushi by using passive hemagglutinin test was 1:80, and serologic tests of leptospirosis and hemorrhagic fever with renal syndrome were all negative. Considering the possibility of doxycycline-resistant scrub typhus, doxycycline was discontinued and he was started on clarithromycin. Since then, he responded well to the treatment with subsidence of the fever and myalgia (Figure 1). Clarithromycin (1,000 mg/d) was given for a total of 7 days. Blood culture was sterile. Convalescent antibody titer against $O$. tsutsugamushi performed during the second week was 1:320.

\section{DISCUSSION}

Scrub typhus is a chigger-borne disease caused by the rickettsia Orientia tsutsugamushi. The disease is endemic in Asia and remains an important public health problem. Most cases of scrub typhus occur in rural areas, but cases may also occur in suburban areas. It is listed as one of the differential diagnoses of fever of unknown origin in endemic areas during the months of October and November. ${ }^{4}$. The illness varies in severity from mild and self-limiting to fatal. After an incubation period of 6 to 21 days, the acute febrile onset is characterized by headache, sweating, conjunctival injection, and lymphadenopathy. There may be an accompanying maculopapular rash, an eschar at the site of chigger feeding.

Antibiotic treatment is thought to shorten the illness and reduce mortality. O. tsutsugamushi was previously thought to be so highly susceptible to tetracycline drugs that the rapidity of defervescence after the initiation of treatment was used to confirm a presumptive diagnosis. After a single oral dose of $200 \mathrm{mg}$ of doxycycline, $90 \%$ of patients were afebrile within 48 hours $^{5}$. In one study involving 42 adults treated with a single dose of $200 \mathrm{mg}$ doxycycline, $88 \%$ became afebrile and all clinical symptoms disappeared within 72 hours. ${ }^{6}$. In two series in Vietnam, fever resolved with tetracycline within 48 hours in $90 \%$ and $100 \%$ of patients, respectively ${ }^{7,8}$.

The slow response to treatment could have resulted from infection by more virulent strains of O. tsutsugamushi, from infection by resistant strains, or both. Song et al reported treatment failure in $4 / 66$ participants in the doxycycline group ${ }^{9}$. In a case series from Thailand, strains of $O$. tsutsugamushi with reduced susceptibility to doxycycline were reported; the median fever clearance time for patients with doxycycline-resistant strains of $O$. tsutsugamushi was 80 hours $^{10}$. Kim et al found that 7 patients (15.2\%) were reported with fever persisted for more than 80 hours among doxycyclinetreated group ${ }^{11}$. Based on above-mentioned data, we might suspect doxycycline resistant case because of the sustained fever and myalgia after 96 hours of doxycycline treatment.

The new macrolide antibiotic, azithromycin was 
effective against some strains of $O$. tsutsugamushi, particularly doxycycline resistant strains ${ }^{12}$. Azithromycin causes no known harm to young children and pregnant women. It has advantages over chloramphenicol, which occasionally causes bone marrow suppression, and tetracycline, which affects the growing bones and teeth of children and fetuses. Clarithromycin, with which we substituted doxycycline, was also reported to be effective for $O$. tsutsugamushi $i^{13,14}$. Because the annual incidence of scrub typhus has increased sharply, there is also growing concern about the possibility of doxycycline resistant strain in Korea. Therefore, it is necessary to test the susceptibility of $O$. tsutsugamushi to doxycycline. However, culture of O. tsutsugamushi can be performed in specialized centers with the necessary laboratory facilities and diagnostic reagents. Unfortunately feasible microbiological diagnostic tests are unavailable in Korea.

Sustained fever in this case may be caused by another condition, such as more virulent strain and poor drug absorption, other than drug resistant scrub typhus. Therefore, besides antibiotic susceptibility test, serum drug concentration also needs to be tested if available. However, otherwise, there was no apparent focus of persistent fever on examination, and sustained fever with myalgia despite doxycycline trial disappeared promptly to substituted clarithrimycin. This case shows clinically the possibility of doxycycline resistant scrub typhus in Korea although not confirmed microbiologically. There is a need to characterize doxycycline resistant scrub typhus in the near future.

\section{CONCLUSION}

Doxycycline-resistant strain of $O$. tsutsugamushi has not been isolated in Korea. But the risk of emerging of doxycycline resistant scrub typhus may be expected. Therefore, it is important to suspect clinically doxycycyline-resistant scrub typhus if there is a sustained fever without identifiable cause after doxycycline trial and alternative antibiotics may be considered.

\section{REFERENCES}

1. Korea Center for Disease Control and Prevention. CDMR Communicable Disease Monthly Report 2006; 17:11.

2. Wisseman CL. Rickettsias. In: Davis BD, Dulbecco R, Eisen HN ,Ginsberg HS, editors. Microbiology. Philadelphia: Lippincott; 1990. p. 687-97.

3. Brown GW. Scrub typhus: pathogenesis and clinical syndrome. In: DH Walker, editor. Biology of rickettsial diseases, volume 1. Boca Raton, FL: CRC Press; 1988. p. 94-100.

4. Chang WH. Current status of tsutsugamushi disease in Korea. J Korean Med Sci 1995;10:227-38.

5. Brown GW, Saunders JP, Singh S, Huxsoll DL, Shirai A. Single dose doxycycline therapy for scrub typhus. Trans R Soc Trop Med Hyg 1978;72:412-6.

6. Supparatpinyo K, Horsin P, Hirunsri P. Scrub typhus: Single oral doxycycline therapy in mild to moderately severe cases. J Infect Dis Antimicrob Agents 1990; 7:135-7.

7. Sheehy TW, Hazlett D, Turk RE. Scrub typhus: a comparison of chloramphenicol and tetracycline in its treatment. Arch Intern Med 1973;132:77-80.

8. Berman SJ, Kundin WD. Scrub typhus in South Vietnam: a study of 87 cases. Ann Intern Med 1973; 79:26-30.

9. Song JH, Lee C, Chang WH, Choi SW, Choi JE, Kim YS, et al. Short course doxycycline treatment versus conventional tetracycline therapy for scrub typhus: a multiple randomized trial. Clin Infect Dis 1995; 21:506-10.

10. Watt G, Chouriyagune C, Ruangweerayud R, Watcharapichat $\mathrm{P}$, Phulsuksombati $\mathrm{D}$, Jongsakul $\mathrm{K}$, et al. Scrub typhus infections poorly responsive to antibiotics in northern Thailand. Lancet 1996;348: 86-9.

11. Kim YS, Yun HJ, Shim SK, Koo SH, Kim SY, Kim S. A comparative trial of a single dose of azithromycin versus doxycycline for the treatment of mild scrub 
typhus. Clin Infect Dis 2004;39:1329-35.

12. Strickman D, Sheer T, Salata K, Hershey J, Dasch G, Kelly D, et al. In vitro effectiveness of azithromycin against doxycycline resistant and susceptible strains of Rickettsia tsutsugamushi, etiologic agent of scrub typhus. Antimicrob Agents Chemother 1995;39:240610.
13. Fischer BP, Muller A, Strauss R, Schneider HT, Hahn EG. Tsutsugamushi fever. Rare rickettsiosis after a stay in the Philippines. Dtsch Med Wochenschr 1998; 123:562-6.

14. Jung EM, Moon KH, Yoe SY, Eum SJ, Lee JH, Jo SR. Clarithromycin Therapy for Scrub Typus. Korean J Pediatr Infect Dis 2002;9:175-81. 